\title{
Empowering Saudi Women through Social Welfare Policies in Judiciary
}

\author{
Haifa Abdul Rahman Saleh Shalhoub \\ College of Social Work, Princes Nourah Bint Abdualrahman University, Kingdom of Saudi Arabia \\ *Corresponding Author: dr.haifaa2000@hotmail.com
}

\begin{abstract}
The author interviewed 338 faculty members out of a total of 2648, and interviewed 55 Shura's Council members in order to understand developing strategies to empower Saudi women in the field of judiciary through the framing of social welfare policies.
\end{abstract}

Keywords Empowerment, Saudi Women, Social Welfare Policies, Judiciary, Social Exclusion

\section{Introduction}

Many social scientists have viewed that the role of Saudi women remains fundamental within the family structure and, in turn, anything a woman does in addition to caring for her family is often considered to be unnecessary, and even supposed as a luxury (Hamdan, 2012, pp: 200-220).

Social change that has occurred in the role of the Saudi family, in terms of its commitment to the traditions and customs, along with what the traditional roles of women in the life cycle, impose them on taking responsibilities not only towards themselves but also their families in particular and communities at large (Göle, 2000, pp: 91-117).

Saudi Arab society considers the family- tribe as the basis of the social structure, and the individual derives a social network and assistance in times of need from the family. (Metz, 1992).

In North America and much of Europe, welfare reforms restructured the systems of social provisions over the last two decades. Some scientists have worked and continue to work in this field-ranging from policy oriented to theoretically inclined social scientists. Most of these researchers focus on a national context, albeit their methodological, analytical, and political perspectives vary. While majority refer to shifts in policies taking place in the neighboring countries, most of them have refrained from welfare development analyzing all sides of human at social environment (Sylvia, 2002, p.1).

In judicial proceedings, procedural safeguards and appellate reviews are generally viewed as the guardians of fairness and accuracies.

So, adjustments in either the procedural rules, or the evidentiary system, the adjective law governing the process of adjudication efforts, over the past several decades to develop rules, which strike an appropriate balance between the information-seeking and the harassment potential of various discovery devices provide obvious and familiar examples of the kinds of adjustments to the adjudicatory process in the courts; this in turn could be an appropriate opportunity for empowering Saudi Women (Jeny, 1972).

This study tried to test the relationship hypotheses, in order to analyze the statistically significant difference between faculty members and Shura's Council members using SWOT analysis aimed at empowering Saudi Women in the field of judiciary. The findings unravel four dimensions of empowering Saudi women. This has been retrieved after analyzing the reality of the social welfare policies and then identifying the strengths, weaknesses, opportunities and threats and trying to build a proposal to enable Saudi women in building an inclusive empowerment strategy particularly in the field of judiciary. The next section reviews the literature on social welfare policies.

\section{Social Welfare Policies}

It is well documented that the United Nations have launched different social welfare policies on gender and development across both the developed and the developing world but social inequalities remain (United Nation, 2009, p. 85, Gerring, John \& Strom Thacker, 2003). These forms of social inequalities are referred to as 'Robin Hood paradox', which means that "advanced democracies with low levels of inequality tend to redistribute more, while those nations with high levels of inequality redistribute less. In an ideal world, however, the correlation should go the other way, as the most unequal democracies have the greatest need for redistribution"(Democracy, Distribution and the Representation of Economic Interests, retrieved from: http://www.russellsage.org/awarded-project/democracy-dist ribution-and-representation-economic-interests). Given the ISSN: 2332-6840 (Online) 2332-6832 (Print) Copyright (C) 2015 by authors, all rights reserved. Authors agree that this article remains permanently open access under the terms of the Creative Commons Attribution License 4.0 International License 
said context, social inequalities continue with respect to education, health assistance, poverty per capita income in addition to gender inequalities (United Nation, 2009). Besides this, the paradox also focuses on the economic aid and structural adjustment programs and the humanitarian goals (Peter, 2004) between the developed and the developing countries. The focus of this research however, is not to redevelop or debate on the Robinhood paradox. Rather, the research aims to empower Saudi women through social welfare policies in judiciary. Notwithstanding, many observations about "new social risks" are identified when designing social policies under the paradigm of welfare states (Torben, Iversen, \& David Soskice 2008). Examples of the nuanced/myriad social risks might emerge while redistributing income through social insurance, food security, cash transfer, free access to health, education, etc. Nonetheless, despite varied social risks identified while framing welfare policies, the aim of all welfare policies are to bestow social protection to its poor and needy( see, Burgoon, 2006).

In addition, social exclusion as a highly contested term, emerged in the UK in the mid-1990s, not only attracted explicit focus on the government policies but also much of academic attention (Understanding Social Exclusion, Case brief 23 June 2002, p.1, Centre for analysis of social exclusion an ESRC research, retrieved from: http://sticerd.lse.ac.uk/dps/case/cb/CASEbrief23.pdf).

This research, however, does not engage on the notion of social exclusion. Nonetheless, the research acknowledges that the incorporation of this notion in social welfare policy emphasizes the very nature of the policy, making it much richer in policy responses. Arguably, the notion 'social exclusion' is a road to shaping social justice outcomes among the marginalized and the poor (Understanding Social Exclusion, Case brief 23 June 2002, p.1, Centre for analysis of social exclusion an ESRC research, retrieved from: http://sticerd.lse.ac.uk/dps/case/cb/CASEbrief23.pdf).

Seemingly, feminist research increasingly argues for a woman's role in the family in both the developed and the developing nations. Policies based on the traditional family and intended to support it are being disrupted by changes in marriage and work. The traditional model is increasingly adrift from the real world, but in this respect, welfare structures have changed more slowly than work and families in the 1980s and 1990s. Welfare structures reflect men's power in the workplace, family and the state; but welfare provisions are crucially important to women as carers, who may have little or no personal income. That said, "increas[ing] family responsibilities weigh more heavily on women" as the burden of household chores fall mainly on a woman than the man, (Gillian Pascall, 1997, p.2), of course the degree of such responsibilities vary from household to household, society to society over space and time. In this context, a Saudi Arabian woman as a nurturer and carer is no exception. In fact, a Saudi Arabian woman is the key backbone of a household structure. Considering these backgrounds, this research aims to build a checklist based on the opinion of the participants aimed at increasing opportunities and enabling empowerment of Saudi women in the in the field of judiciary.

\section{Judiciary}

Judges as legislators play important roles in delivering judicial decisions in hard appellate cases.(Anthony D'Amato, 2010). In Saudi Arabia, the judicial system is based mainly on Sharia codes that commands jurisdiction over both criminal and civil cases. The Saudi judiciary is a part of the Government of Saudi Arabia comprising of lawyers and judges, who also form a part of Islamic religious hierarchies and leadership (qadis, muftis and ulamas).While the Saudi judiciary is highly justice-sensitive, it is the purpose of this research to appeal for a gender-sensitive judiciary, entailing empowerment of Saudi women through the process of judiciary. The research therefore calls for framing of social welfare policies within the judiciary of Saudi Arabia, which in turn would empower women. In the next section, the author discusses about empowerment.

\section{Empowerment}

Although empowerment is a 'buzzword', it is an important indicator of development. In any society, women's empowerment remains vital in not only achieving economic and sustainable development, but also, in building the quality of lives for the women themselves and their families and the surrounding communities. This argument is increasingly reinforced by research conducted by UNDP, UNIFEM, and the World Bank, among others, which indicates that gender inequalities in developing societies inhibit economic growth and development. Hence, for a woman to be empowered, she needs to gain access to the material, human, and social resources necessary to make strategic choices in her life. Not only have women been historically disadvantaged in access to material resources like credit, property, and money, but they have also been excluded from social resources like education or insider knowledge of some businesses. A 2001World Bank report argues that those societies that discriminate on the basis of gender pay the cost of greater poverty, slower economic growth, weaker governance, and a lower living standard of their people, so that overall, evidence is mounting that improved gender equality is a critical component of any development strategy (Susy Cheston, and Lisa Kuhn, 2002). Hence, to seek for women's empowerment, one must consider the factors affecting women's status and rights (Rachel Cichowski 2005). Moreover, one must determine the relation between the concept of empowerment and the formation of civil society bodies, such as NGOs, through Social Welfare Policies in Judiciary (Aradhana Sharma, 2006, 62). In this context, using an empowerment approach, this research aims at constructing a strategy to empower Saudi women in the field of judiciary by framing social welfare policies. 


\section{Materials and Methods}

\section{Research Methodology}

This is a triangulated two-shot research conducted via empowering Saudi Women in judiciary. For this, we circulated two questionnaires: the first was conducted among the faculty members in five universities at K.S.A. The second was administered among the Shura's Council of members comprising five committees). A detailed demographic sheet was used to collect information from the faculty members and Shura's Council members (using the supplementary 1sheet). Mean, Standard deviation and Independent sample T-test were calculated along with other scientific test techniques. Purposive sampling technique was used by conducting a survey, which was conducted among 338 faculty members out of a total 2648 faculty members, and 55 Shura's Council members in five committees. The questionnaire was divided into three sections. The first section concentrated on measuring demographic information of the respondents. Section 2 was dedicated to retrieve information regarding the concept of empowerment and its varied fields, needs and levels. Section 3 consisted of questions regarding the reality of framing social welfare policies for Saudi women in judiciary.

\subsection{Research Objective}

This research aims to build a strategy to emancipate Saudi women through the development of social welfare policies in the field of judiciary using empowerment approach. The key objectives of this research are:

1. determine the vision of the concept of empowerment of Saudi women in the field of judiciary.

2. To analyze the reality of social welfare policies of Saudi women in judiciary.

For this, the research aims to build strategies:

a) decision making

b) problem solving

c) and on empowerment strategies.

\section{Results and Discussion}

The sampling size, response rate and demographic data analysis are provided in the Fig. 1, which include ffirst, the faculty members' sample, second, the Shura's Council members' sample\}. The value of Cronbach's alpha test used to check the reliability of the instruments illustrated in Table 2 , which is perceived to be very good.

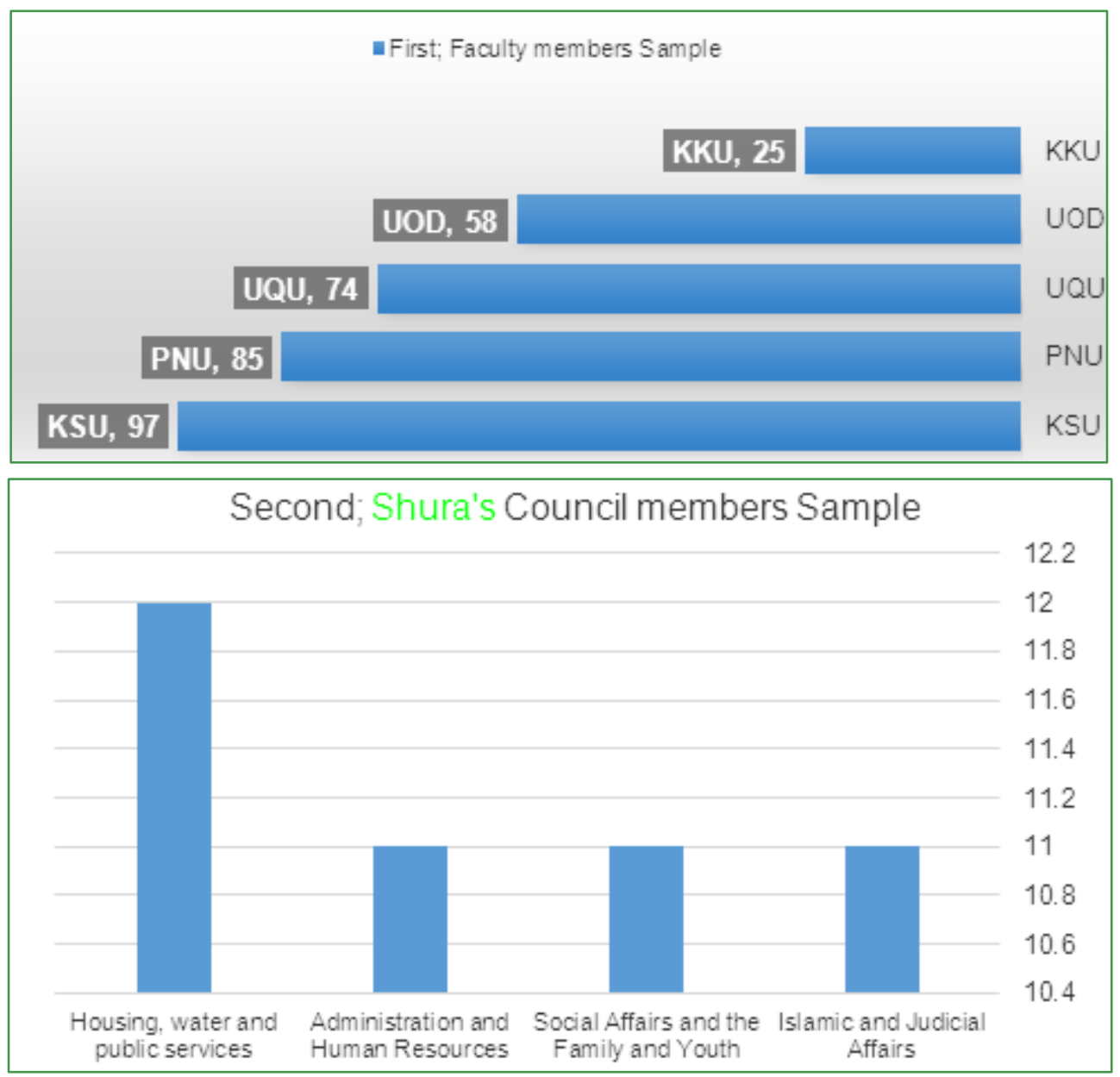

Figure 1. Population, sample and response analysis 
Table 2. Reliability analysis- scale(alpha)

\begin{tabular}{cc}
\hline Reliability coefficients & \\
\hline No. of cases $=15$ & No. of Items $=39$ \\
\hline Alpha $=.884$ & \\
\hline
\end{tabular}

Table 3. Sample responses on the axis of the strengths phrases In descending order according to the averages of approval

\begin{tabular}{|c|c|c|c|c|}
\hline Item & Sample & Mean & SD & Ranking \\
\hline \multirow{2}{*}{$\begin{array}{l}\text { The judicial system to } \\
\text { solve most of the } \\
\text { problems of women }\end{array}$} & $\begin{array}{l}\text { Faculty } \\
\text { members }\end{array}$ & 2.68 & .614 & \multirow[b]{2}{*}{1} \\
\hline & $\begin{array}{l}\text { Shura's } \\
\text { Council } \\
\text { members }\end{array}$ & 2.3 & .839 & \\
\hline \multirow{2}{*}{$\begin{array}{l}\text { The judicial system } \\
\text { deal Saudi woman } \\
\text { deal as an independent } \\
\text { person }\end{array}$} & $\begin{array}{c}\text { Faculty } \\
\text { members }\end{array}$ & 2.67 & .652 & \multirow[b]{2}{*}{2} \\
\hline & $\begin{array}{l}\text { Shura's } \\
\text { Council } \\
\text { members }\end{array}$ & 2.28 & .927 & \\
\hline \multirow{2}{*}{$\begin{array}{l}\text { Allow women to plead } \\
\text { in the courts and } \\
\text { personal status cases }\end{array}$} & $\begin{array}{c}\text { Faculty } \\
\text { members }\end{array}$ & 2.62 & .640 & \multirow[b]{2}{*}{3} \\
\hline & $\begin{array}{l}\text { Shura's } \\
\text { Council } \\
\text { members }\end{array}$ & 2.36 & .749 & \\
\hline \multirow{2}{*}{$\begin{array}{l}\text { The drafting of } \\
\text { judicial laws related } \\
\text { to women's rights } \\
\text { women's }\end{array}$} & $\begin{array}{c}\text { Faculty } \\
\text { members }\end{array}$ & 2.64 & .670 & \multirow[b]{2}{*}{4} \\
\hline & $\begin{array}{l}\text { Shura's } \\
\text { Council } \\
\text { members }\end{array}$ & 2.06 & .936 & \\
\hline \multirow{2}{*}{$\begin{array}{l}\text { Equality of the judicial } \\
\text { system between men } \\
\text { and women within the } \\
\text { Islamic law }\end{array}$} & $\begin{array}{c}\text { Faculty } \\
\text { members }\end{array}$ & 2.62 & .714 & \multirow[b]{2}{*}{5} \\
\hline & $\begin{array}{l}\text { Shura's } \\
\text { Council } \\
\text { members }\end{array}$ & 2.12 & .872 & \\
\hline
\end{tabular}

Table 4. Sample responses on the axis of the weaknesses phrases In descending order according to the averages of approval

\begin{tabular}{|c|c|c|c|c|}
\hline Item & Sample & Mean & SD & Ranking \\
\hline \multirow{2}{*}{$\begin{array}{l}\text { There is a lack of } \\
\text { personal status } \\
\text { legislation }\end{array}$} & $\begin{array}{c}\text { Faculty } \\
\text { members }\end{array}$ & 2.73 & .574 & \multirow[b]{2}{*}{1} \\
\hline & $\begin{array}{c}\text { Shura's } \\
\text { Council } \\
\text { members }\end{array}$ & 2.64 & .722 & \\
\hline \multirow{2}{*}{$\begin{array}{l}\text { Limited opportunities } \\
\text { for women to work in } \\
\text { the Sharia courts }\end{array}$} & $\begin{array}{c}\text { Faculty } \\
\text { members }\end{array}$ & 2.72 & .536 & \multirow[b]{2}{*}{2} \\
\hline & $\begin{array}{c}\text { Shura's } \\
\text { Council } \\
\text { members }\end{array}$ & 2.50 & .763 & \\
\hline \multirow{2}{*}{$\begin{array}{l}\text { The weakness of } \\
\text { existing laws to cover } \\
\text { the needs of women's } \\
\text { issues }\end{array}$} & $\begin{array}{c}\text { Faculty } \\
\text { members }\end{array}$ & 2.63 & .650 & \multirow[b]{2}{*}{3} \\
\hline & $\begin{array}{c}\text { Shura's } \\
\text { Council } \\
\text { members }\end{array}$ & 2.66 & .626 & \\
\hline \multirow{2}{*}{$\begin{array}{c}\text { Not to allow women to } \\
\text { come to court without a } \\
\text { mahram }\end{array}$} & $\begin{array}{c}\text { Faculty } \\
\text { members }\end{array}$ & 2.64 & .647 & \multirow[b]{2}{*}{4} \\
\hline & $\begin{array}{c}\text { Shura's } \\
\text { Council } \\
\text { members }\end{array}$ & 2.38 & .753 & \\
\hline \multirow{2}{*}{$\begin{array}{l}\text { Shortage of judges in } \\
\text { preparation of specialists } \\
\text { associated with women's } \\
\text { issues }\end{array}$} & $\begin{array}{c}\text { Faculty } \\
\text { members }\end{array}$ & 2.63 & .627 & \multirow[b]{2}{*}{5} \\
\hline & $\begin{array}{c}\text { Shura's } \\
\text { Council } \\
\text { members }\end{array}$ & 2.56 & .644 & \\
\hline
\end{tabular}

Table 5. Sample responses on the axis of the opportunities phrases In descending order according to the averages of approval

\begin{tabular}{|c|c|c|c|c|}
\hline Item & Sample & Mean & SD & Ranking \\
\hline \multirow{2}{*}{$\begin{array}{l}\text { Go to the courts } \\
\text { concerned with } \\
\text { the allocation of } \\
\text { women's issues in } \\
\text { relation to family } \\
\text { matters }\end{array}$} & $\begin{array}{l}\text { Faculty } \\
\text { members }\end{array}$ & 2.78 & .506 & \multirow{2}{*}{1} \\
\hline & $\begin{array}{l}\text { Shura's } \\
\text { Council } \\
\text { members }\end{array}$ & 2.84 & .548 & \\
\hline \multirow{2}{*}{$\begin{array}{l}\text { The attention of } \\
\text { decision-makers } \\
\text { change the status } \\
\text { of women in } \\
\text { society }\end{array}$} & $\begin{array}{l}\text { Faculty } \\
\text { members }\end{array}$ & 2.72 & .575 & \multirow{2}{*}{2} \\
\hline & $\begin{array}{l}\text { Shura's } \\
\text { Council } \\
\text { members }\end{array}$ & 2.78 & .582 & \\
\hline \multirow{2}{*}{$\begin{array}{l}\text { Create academic } \\
\text { departments to } \\
\text { prepare women in } \\
\text { the field of } \\
\text { judiciary }\end{array}$} & $\begin{array}{l}\text { Faculty } \\
\text { members }\end{array}$ & 2.71 & .548 & \multirow{2}{*}{3} \\
\hline & $\begin{array}{c}\text { Shura's } \\
\text { Council } \\
\text { members }\end{array}$ & 2.68 & .621 & \\
\hline \multirow{2}{*}{$\begin{array}{l}\text { Kingdom signed } \\
\text { the Convention } \\
\text { on the } \\
\text { Elimination of } \\
\text { All Forms of } \\
\text { Discrimination } \\
\text { against Women }\end{array}$} & $\begin{array}{l}\text { Faculty } \\
\text { members }\end{array}$ & 2.63 & .674 & \multirow{2}{*}{4} \\
\hline & $\begin{array}{l}\text { Shura's } \\
\text { Council } \\
\text { members }\end{array}$ & 2.72 & .454 & \\
\hline \multirow{2}{*}{$\begin{array}{l}\text { The issuance of } \\
\text { government's } \\
\text { decisions to allow } \\
\text { women to work in } \\
\text { Sharia courts }\end{array}$} & $\begin{array}{l}\text { Faculty } \\
\text { members }\end{array}$ & 2.64 & .640 & \multirow{2}{*}{5} \\
\hline & $\begin{array}{c}\text { Shura's } \\
\text { Council } \\
\text { members }\end{array}$ & 2.64 & .638 & \\
\hline \multirow{2}{*}{$\begin{array}{l}\text { Global trends of } \\
\text { non-discriminatio } \\
\mathrm{n} \text { between men } \\
\text { and women at } \\
\text { work in the field } \\
\text { of judiciary }\end{array}$} & $\begin{array}{l}\text { Faculty } \\
\text { members }\end{array}$ & 2.58 & .668 & \multirow{2}{*}{6} \\
\hline & $\begin{array}{l}\text { Shura's } \\
\text { Council } \\
\text { members }\end{array}$ & 2,56 & .644 & \\
\hline
\end{tabular}

Table 3 illustrates the strengths of descending order according to the averages of approval in the judicial system. Seemingly, Table 4 , portrays the weaknesses as perceived by the participants. While Table 5 describes opportunities in the judiciary system, Table 6 accounts the threats as perceived by the respondents in the judiciary.

Table 7 illustrates that overall there are no statistically significant differences in the indicators related to enable empowerment of Saudi women in the field of judiciary. SWOT analyses were used to explore the weaknesses, the opportunities, and the threats related to the empowerment of women in the judiciary system. The value of $\mathrm{T}$ between faculty members and Shura's Council members are statistically significant and stands at $\mathrm{p} \leq .01$. There are however statistically significant differences, in the strengths value of $T$ between faculty members and Shura's Council members are statistically significant at $\mathrm{p} \leq .01$. 
Table 6. Sample responses on the axis of the threats phrases In descending order according to the averages of approval

\begin{tabular}{|c|c|c|c|c|}
\hline Item & Sample & Mean & SD & Ranking \\
\hline \multirow[b]{2}{*}{$\begin{array}{l}\text { The lack of human rights } \\
\text { culture among women }\end{array}$} & $\begin{array}{l}\text { Faculty } \\
\text { members }\end{array}$ & 2.79 & .527 & \multirow[b]{2}{*}{1} \\
\hline & $\begin{array}{c}\text { Shura's } \\
\text { Council } \\
\text { members }\end{array}$ & 2.52 & .677 & \\
\hline \multirow{2}{*}{$\begin{array}{l}\text { The lack of awareness in } \\
\text { society regarding } \\
\text { women's rights in the } \\
\text { judiciary }\end{array}$} & $\begin{array}{l}\text { Faculty } \\
\text { members }\end{array}$ & 2.8 & .536 & \multirow[b]{2}{*}{2} \\
\hline & $\begin{array}{l}\text { Shura's } \\
\text { Council } \\
\text { members }\end{array}$ & 2.60 & .606 & \\
\hline \multirow{2}{*}{$\begin{array}{l}\text { Compare the customs } \\
\text { and traditions of the } \\
\text { judicial claim to } \\
\text { women's rights }\end{array}$} & $\begin{array}{l}\text { Faculty } \\
\text { members }\end{array}$ & 2.73 & .566 & \multirow[b]{2}{*}{3} \\
\hline & $\begin{array}{l}\text { Shura's } \\
\text { Council } \\
\text { members }\end{array}$ & 2.80 & .535 & \\
\hline \multirow{2}{*}{$\begin{array}{l}\text { The weakness of } \\
\text { women's knowledge of } \\
\text { litigation procedures }\end{array}$} & $\begin{array}{l}\text { Faculty } \\
\text { members }\end{array}$ & 2.75 & .524 & \multirow[b]{2}{*}{4} \\
\hline & $\begin{array}{l}\text { Shura's } \\
\text { Council } \\
\text { members }\end{array}$ & 2.48 & .646 & \\
\hline \multirow{2}{*}{$\begin{array}{c}\text { The men resistant to the } \\
\text { work of women in the } \\
\text { Sharia courts }\end{array}$} & $\begin{array}{l}\text { Faculty } \\
\text { members }\end{array}$ & 2.68 & .611 & \multirow[b]{2}{*}{5} \\
\hline & $\begin{array}{l}\text { Shura's } \\
\text { Council } \\
\text { members }\end{array}$ & 2.80 & .404 & \\
\hline \multirow{2}{*}{$\begin{array}{l}\text { Discrimination between } \\
\text { men and women in the } \\
\text { prevailing social culture }\end{array}$} & $\begin{array}{l}\text { Faculty } \\
\text { members }\end{array}$ & 2.71 & .601 & \multirow[b]{2}{*}{6} \\
\hline & $\begin{array}{l}\text { Shura's } \\
\text { Council } \\
\text { members }\end{array}$ & 2.58 & .702 & \\
\hline \multirow{2}{*}{$\begin{array}{l}\text { Resistance, customs and } \\
\text { traditions of women's } \\
\text { work in some areas }\end{array}$} & $\begin{array}{l}\text { Faculty } \\
\text { members }\end{array}$ & 2.68 & .610 & \multirow[b]{2}{*}{7} \\
\hline & $\begin{array}{l}\text { Shura's } \\
\text { Council } \\
\text { members }\end{array}$ & 3.72 & .701 & \\
\hline
\end{tabular}

Table 7. Illustrates the results t-test of SWOT

\begin{tabular}{|c|c|c|c|}
\hline SWOT Analysis & Sample & $\mathrm{T}$ & Sig \\
\hline \multirow{2}{*}{ The strengths } & Faculty members & \multirow{2}{*}{3.769} & \multirow{2}{*}{$.000^{* *}$} \\
\hline & Shura's Council members & & \\
\hline \multirow{2}{*}{ The weaknesses } & Faculty members & \multirow{2}{*}{1.340} & \multirow{2}{*}{.186} \\
\hline & Shura's Council members & & \\
\hline \multirow{2}{*}{ The opportunities } & Faculty members & \multirow{2}{*}{-.336} & \multirow{2}{*}{.738} \\
\hline & Shura's Council members & & \\
\hline \multirow{2}{*}{ The threats } & Faculty members & \multirow{2}{*}{1.314} & \multirow{2}{*}{.190} \\
\hline & Shura's Council members & & \\
\hline
\end{tabular}

$* \mathrm{p} \leq .01$

\section{Conclusions}

This research aimed at probing and ensuring women's equality in terms of rights and duties in accordance with the provisions of Islamic Sharia. In addition, the research tried to address the implementation system in the judiciary in relation to the issues related to custody and visitation, alimony and marital issues. Alongside, it also tried to highlight upon the establishment of departments for mending fences and Family Welfare in the courts and NGOs.

There are some weaknesses facing Saudi women in the judiciary, including a) the absence of protection of women and deterrent sanctions regimes, (b) Lack of proper mechanism to follow up the implementation of court rulings in favor of women exposing them to violence or blackmail, (c) Different judges' deal with one issue, as in marital disputes and divorce issues.

The study found strategies for empowering Saudi women through framing of social welfare policies in judiciary, which include (a) establishment of specialized courts for the adjudication of all cases related to women's issues; (b) establishment of women's units in police stations to receive and address complaints from women, (c) the establishment of colleges and institutes for security studies for women,

(d) the establishment of social work offices in the courts to follow up the case of women who are until now separated from their cases

(e) the establishment of offices to follow up the implementation of court rulings issued in favor of women

\section{Acknowledgements}

We are very grateful to the Promising Research center in Social Research and Women's Studies at Princes Nourah Bint Abdualrahman University, KSA.

\section{REFERENCES}

Anthony, D. (2010). Judicial Legislation. Northwestern University School of Law. Retrieved from

http://scholarlycommons.law.northwestern.edu/facultyworkingpap ers/107

Aradhana, S. (2006). Crossbreeding institutions, breeding struggle: women's employment, neoliberal governmentality, and state $(\mathrm{Re})$ formation in India. Retrieved from http://wesscholar.wesleyan.edu/div2facpubs

Burgoon, B. (2006). Social welfare policies and political economic roots of terrorism. Journal of conflict resolution, vol.50 no. 2, 176-203 doi: $10.1177 / 0022002705284829$ (C) 2006 sage publications.

Centre for analysis of social exclusion an ESRC research. (2002). Retrieved from http://eprints.lse.ac.uk/51311/1/CASEbrief23.pdf

Federal ministry of labour and social affairs (2015). Social security at glance 2015. Germany, referat information, publikation, redaction 53107 Bonn \& María Martínez, S. v Freistaat, B. (1998). Judgment of the Court of 12 May 1998. Case C-85/96.

Gerring, J., \& Strom T. (2003). Social Democracy: Liberalism and Human Development. Retrieved from

http://www.bu.edu/sthacker/IMRpolicy.pdf

Gillian, P. (1997). Social Policy: A new feminist analysis. 11 New Fetter Lane, London EC4P 4EE. Retrieved from http://samples.sainsburysebooks.co.uk/9781134857968_sample_5 32191.pdf 
Göle, N. (2000). Snapshots of Islamic maternities. Daedalus.

Graetz, M., \& Jerry L. (1999). True security: rethinking American social insurance. New Haven, CT: Yale University Press.

Hacker J. (2004). Privatizing Risk without Privatizing the Welfare State: The Hidden Politics of Social Policy Retrenchment in the United States. American Political Science Review, Vol. 98, No.2, p.7 2004, http://apsanet3b.inetu.net/imgtest/hacker\%20APSR $\% 20$ (Maypercentage2004).pdf

Hamdan, A.A. (2012). The role of authentic Islam: The way forward for women in Saudi Arabia. Hawwa, 10, 3, p. 200-220, Scopus ${ }^{\circledR}$, EBSCOhost, [viewed 2 July 2013).

Jeny L., M. (1972). Quality Assurance Systems in the Adjudication of Claims of Entitlement to Benefits on Compensation. Retrieved from https://www.acus.gov/

John A. (1994). Critical concepts. New York. Routledge 11 New Fetter Lane, London EC4P 4EE \& 29 West 35th Street NY 10001, 1st, ISBN 0-203-41992-8.

Metz H. (1992). Cultural Homogeneity and Values. U.S. Library of Congress. Retrieved from: http://countrystudies.us/saudi-arabia/21.htm.

Peter L., H. (2004). Growing public: Social Spending and Economic Growth Since the Eighteenth Century. Vols. 1-2. Cambridge, UK: Cambridge University Press..

Rachel C. (2005). Women's rights, the European court and supranational constitutional. Austin, Texas, Law \& Society Review, 38: 489-512.

Susy, C. \& Lisa, K. (2002). Empowering women through microfinance. Retrieved from

http:/gamechangenetwork.info/documents/GenderMainstreaming/ FinancialServices/Gender\%20Impact/ChestonandKuhn_2002.pdf.

Sylvia B. (2002). Welfare Hot Buttons. Women, Work, and Social Policy Reform. University of Toronto Press, p.1. Retrieved from: http://www.arts.ualberta.ca/cjscopy/reviews/welfarehot.html

Torben, I., \& David S. (2008). Democracy, Distribution and the Representation of Economic Interests. Retrieved from: http://www.russellsage.org/awarded-project/democracy-distributio $\mathrm{n}$-and-representation-economic-interests.

United Nation. (2009). Rethinking Poverty. Report on the World Social Situation 2010. New York. 